\title{
Mass Transfers and Sedimentary Budgets in Geomorphologic Drainage Basin Studies
}

\author{
Achim A. Beylich \\ Geological Survey of Norway (NGU), Quaternary Geology \& Climate group and \\ Norwegian University of Science and Technology (NTNU), Department of Geography \\ Trondheim, \\ Norway
}

\section{Introduction}

Geomorphologic processes, operating at the Earth surface and being responsible for transferring sediments and effecting landform change, are highly dependent on climate, and it is anticipated that climate change will have a major impact on the behaviour of Earth surface systems. Accordingly is geomorphologic research on mass transfers in a variety of different climatic environments represented by a substantial body of literature.

Studies on mass transfers and sedimentary source-to-sink fluxes generally refer to the development of sedimentary budgets. A sediment budget is an accounting of the sources and disposition of sediment as it travels from its point of origin to its eventual exit from a defined landscape unit like a drainage basin (e.g. Reid \& Dunne, 1996). Accordingly, the development of a sediment budget necessitates the identification of processes of weathering, erosion, transport and storage / deposition within a defined area, and their rates and controls (Reid \& Dunne, 1996; Slaymaker, 2000; Beylich \& Warburton, 2007). A thorough understanding of the current sediment production and flux regime within a system is fundamental to predict likely effects of changes to the system, whether climatic induced or human-influenced. Source-to-sink sedimentary flux and sediment budget research therefore enables the prediction of changes to erosion and sedimentation rates, knowledge of where sediment will be deposited, how long it will be stored and how much sediment will be remobilised (Gurnell \& Clark, 1987; Reid \& Dunne, 1996; Beylich \& Warburton, 2007).

Sedimentary mass transfers move eroded sediments from their source area to an area of temporal storage or long-term deposition in sinks. Rates of sediment transfer are not only conditioned by competence of geomorphic processes but also by the availability of sediment for transport. Accordingly, in assessing sediment transfer we need to quantify the forces, which drive transport processes but equally account for the factors, which control sediment supply (e.g. Ballantyne, 2002; Warburton, 2007). Small-scale geomorphologic process and sediment budget studies focus on sedimentary fluxes from areas of weathering and erosion to areas of storage within defined landscape units like drainage basins (Beylich \& Warburton, 2007; Beylich \& Kneisel, 2009), whereas large-scale sediment systems couple headwaters to oceanic sinks.

The identification of storage elements and sinks is critical to the effective study and understanding of source-to-sink sedimentary fluxes (Reid \& Dunne, 1996). The setting of a 
particular drainage basin defines the boundary conditions for storage within that landscape unit. Within a defined landscape unit like a drainage basin, the slope and valley infill elements constitute the key storage units and storage volumes are important for addressing time-dependent sediment budget dynamics. Dating of storage in sedimentary source-to-sink flux studies is applied to determine or estimate the ages and chronology of the storage components within the system. An understanding of the nature of primary stores, secondary stores and the potential storage capacities of different types of drainage basins is important along with knowledge of sediment residence times. Of growing importance within geomorphologic drainage basin research is the development of innovative field methods, such as modern surface process monitoring techniques (Beylich \& Warburton, 2007) and geophysical techniques for estimating sediment storage volumes (Schrott et al., 2003; Sass, 2005; Hansen et al., 2009). Within large-scale sediment systems oceanic sinks are most important and provide the opportunity to estimate rates of sediment production and delivery at long-term temporal as well as continental spatial scales (e.g. Rise et al., 2005; Dowdeswell et al., 2006).

In this chapter on mass transfers and sedimentary budgets in geomorphologic drainage basin studies results on mass transfers and sedimentary budgets from small and nonglaciated drainage basin geo-systems in Iceland (Hrafndalur and Austdalur) and Sweden (Latnjavagge) are presented and discussed as selected examples for field-based and process oriented geomorphologic drainage basin research. The presented material is a summary of key results from longer-term geomorphic studies (starting in 1996 in Iceland and in 1999 in Sweden) and relates to a number of publications where more details on methodology, drainage basin instrumentation and the spatio-temporal variability of geomorphic process rates within the drainage basins can be found.

\section{Mass transfers, sediment budgets and relief development in small rainage basin geo-systems}

Until today, there has only been a very limited number of truly integrated-quantitative studies of geomorphologic mass transfers, sediment budgets and relief development in drainage basins (e.g. Jäckli, 1957; Rapp, 1960; Caine, 1974; 2004; Caine \& Swanson, 1989; Barsch, 1981; Barsch et al., 1994; Warburton, 1993; 2006; Becht, 1995; Beylich, 2000; 2008; Beylich \& Warburton, 2007; Beylich \& Kneisel, 2009; Beylich et al., 2005; in press; Schrott et al., 2002; 2003; Otto \& Dikau, 2004; Slaymaker, 2008; Burki et al., 2009; Hansen et al., 2009). There is especially a significant lack of longer-term (about ten or more years of continuous field research and process monitoring in the defined drainage basin) quantitative process studies despite the fact that longer-term monitoring programmes are necessary for the calculation of reliable contemporary process rates, mass transfers and sediment budgets (e.g. Beylich \& Warburton, 2007).

Geomorphic processes, operating within drainage basins, transferring sediments and changing landforms are highly dependent on climate, vegetation cover and human impact and will be significantly affected by climate change (e.g. Rapp, 1985; Barsch, 1993; Evans \& Clague, 1994; Haeberli \& Beniston, 1998; Lamoureux, 1999; Lamoureux et al., 2007; Slaymaker et al., 2003; Orwin \& Smart, 2004; Beylich et al., 2006b; 2008; Beylich \& Warburton, 2007; Beylich \& Kneisel, 2009; Cockburn \& Lamoureux, 2007; Slaymaker, 2008). An improved quantitative knowledge of mass transfers by sedimentary transfer processes 
operating in present-day climates is needed to model and determine the possible consequences of predicted climate change. It is therefore necessary to collect and compare extended data on both contemporary sedimentary fluxes and on storage elements (for the calculation of long-term process rates, e.g. on the Holocene timescale) from a wide range of different global environments and to apply more standardised methods for research on sediment fluxes and relationships between climate and sedimentary transfer processes (Beylich et al., 2006a; 2008; Beylich \& Warburton, 2007; Lamoureux et al., 2007). Comparable datasets on process rates and mass transfers collected in drainage basins from different environments can then be used to model possible effects of predicted climate change as well as trends of relief development by applying the Ergodic principle of space-for-time substitution (e.g. Beylich et al., 2006a; 2008; Beylich \& Kneisel, 2009).

\subsection{Study areas}

Results of field-based geomorphologic research on mass transfers, sediment budgets and relief development from three small and non-glaciated selected drainage basin geo-systems in eastern Iceland (Hrafndalur and Austdalur) and northern Swedish Lapland (Latnjavagge) are presented.

The Hrafndalur $\left(7 \mathrm{~km}^{2}, 6\right.$ - $731 \mathrm{~m}$ a.s.1.; $\left.65^{\circ} 28^{`} \mathrm{~N}, 13^{\circ} 42^{\circ} \mathrm{W}\right)$ and the Austdalur drainage basin $\left(23 \mathrm{~km}^{2}, 0-1028 \mathrm{~m}\right.$ a.s.l.; $\left.65^{\circ} 16^{\wedge} \mathrm{N}, 13^{\circ} 48^{\circ} \mathrm{W}\right)$ are situated in the Easter Fjords region (Austfirðir) of eastern Iceland (Figs 1 - 3).

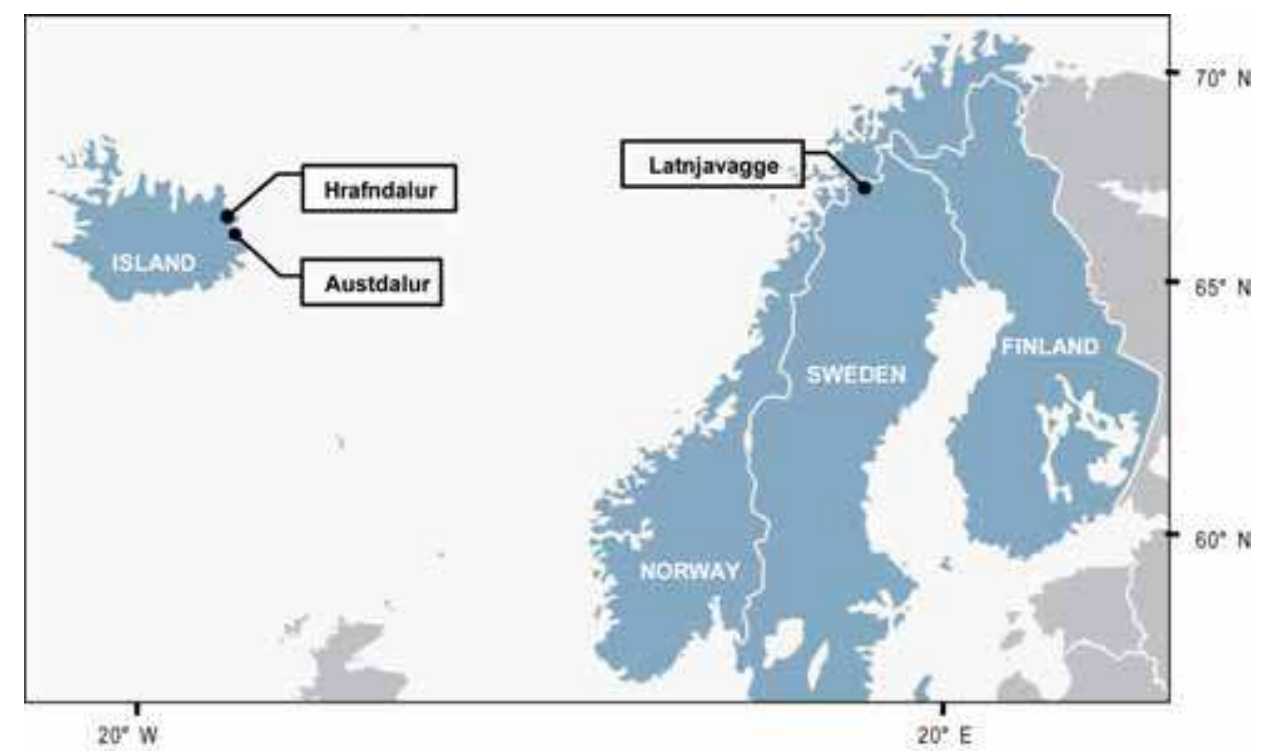

Fig. 1. Locations of the Hrafndalur, Austdalur and Latnjavagge drainage basins

The climate of the Eastern Fjords region is sub-Arctic oceanic, with a mean annual precipitation of $1719 \mathrm{~mm} \mathrm{yr}^{-1}$ in Hrafndalur and $1431 \mathrm{~mm} \mathrm{yr}^{-1}$ in Austdalur, and a mean annual air temperature of $3.6^{\circ} \mathrm{C}$ in both drainage basins. Runoff occurs year-round with the highest channel discharges happening during spring snow melt (normally April - June), 
wintry thaw events and especially during extreme rainfall events, which are normally most frequent in fall (September - November) (Beylich, 1999; 2003; 2009). During dry spells in

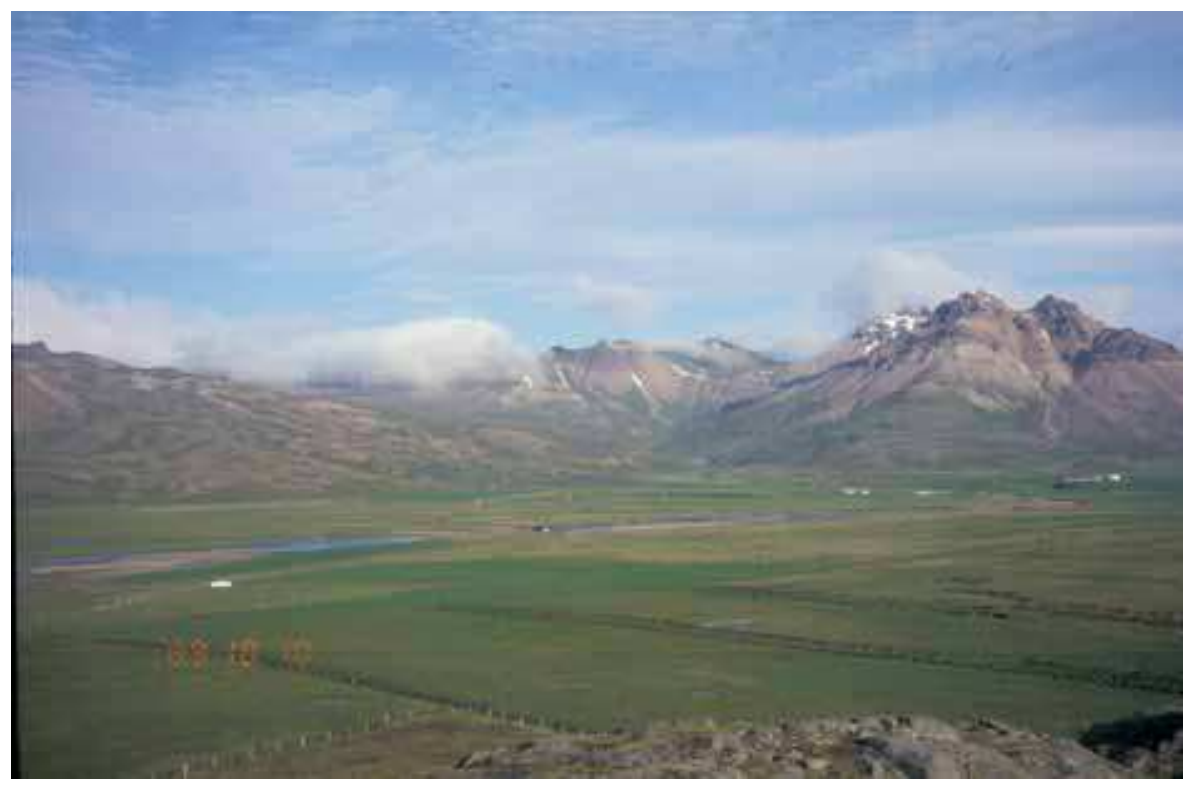

Fig. 2. The Hrafndalur drainage basin in eastern Iceland

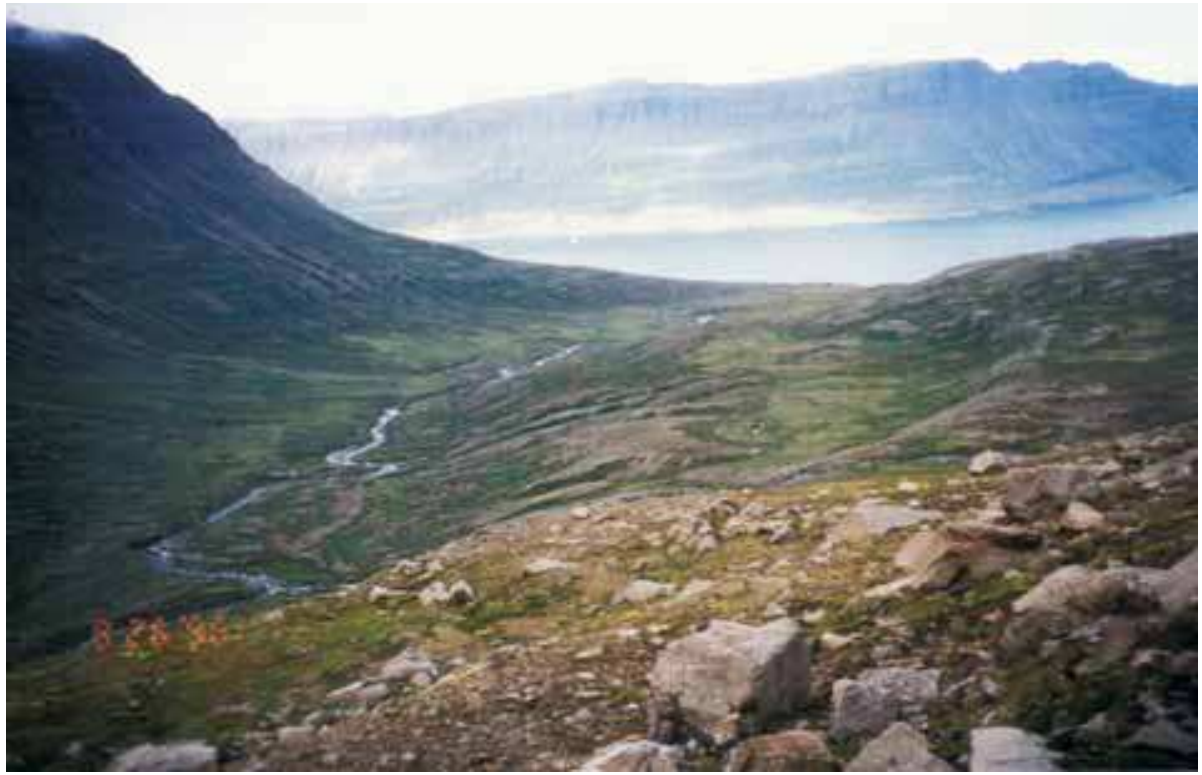

Fig. 3. The Austdalur drainage basin in eastern Iceland 
summer and frost spells in winter runoff can be very low and the Hrafndalur drainage basin can be even without any runoff (Beylich, 2003; 2009; Beylich \& Kneisel, 2009). The steep and glacially sculptured relief of both drainage basins is Alpine, with slopes being composed of rock faces and talus cones, and main channels changing between resistance-limited bedrock channels and channel stretches with temporary storage of bed load material (Figs 2 and 3). Regional deglaciation occurred about 8000 yr BP. The lithology in Hrafndalur is clearly dominated by rhyolites and basalt occurs only in some smaller intrusions and dykes. Compared to that, Austdalur is clearly dominated by basalt. Vegetation in both drainage basins includes lichens, mosses, meadows, bogs and dwarf shrubs. Relevant denudative processes are rock and boulder falls, avalanches, debris flows and slides, creep processes, slope wash, chemical denudation, fluvial transport of solutes, suspended sediments and bed load, and deflation. The main storage elements in the valleys are extended talus cones, which are partly inter-fingering with till deposits. In addition, Holocene valley infills are found in the lower parts of both valleys. Dominant soils are regosols and lithosols. There is no permafrost within both Hrafndalur and Austdalur. Direct human impact exists in form of grazing which has caused a significant disturbance of the vegetation cover in larger parts of the drainage basins (Figs 2 and 3) (Beylich, 2000; 2007; Beylich \& Kneisel, 2009).

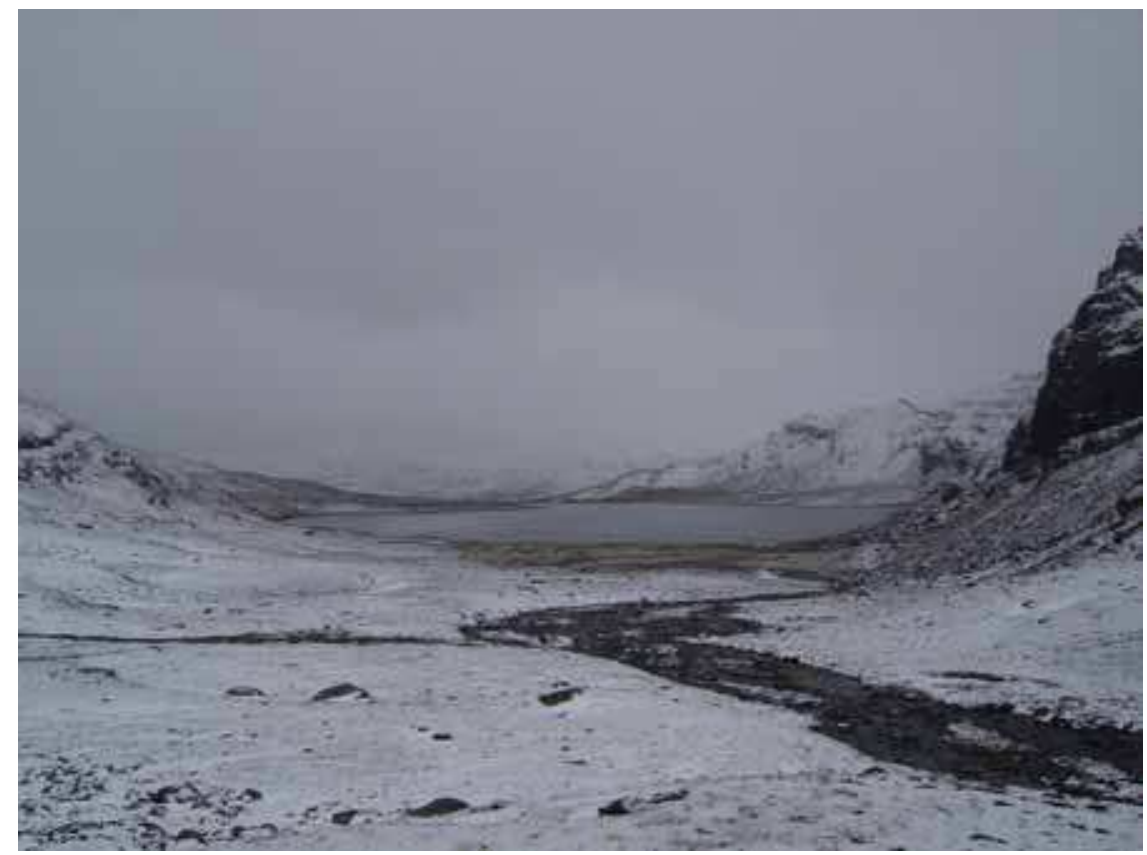

Fig. 4. The Latnjavagge drainage basin in Swedish Lapland

The Latnjavagge drainage basin $\left(68^{\circ} 20^{\prime} \mathrm{N}, 18^{\circ} 30^{\circ} \mathrm{E} ; 9 \mathrm{~km}{ }^{2} ; 950-1440 \mathrm{~m}\right.$ a.s.l. $)$ is situated in the Abisko Mountain Area in northernmost Swedish Lapland (Figs 1 and 4). The Arcticoceanic climate of the area (Beylich, 2003) is characterized by a mean annual temperature of $-2.0^{\circ} \mathrm{C}$ and a mean annual precipitation of $852 \mathrm{~mm} \mathrm{yr}^{-1}$. July is the warmest month (mean $8.6^{\circ} \mathrm{C}$ ). The coldest month is February (mean $-9.4{ }^{\circ} \mathrm{C}$ ). About $2 / 3$ of the annual precipitation is temporarily stored as snow during the winter. Snowmelt normally starts at the end of 
May/beginning of June. Stable freezing temperatures with little daily fluctuation at $10 \mathrm{~cm}$ above ground and autumn snow accumulation usually occur from September/October onwards. Regarding the summer months June - August, August shows the highest mean precipitation $(82 \mathrm{~mm})$ and also the highest frequency of extreme rainfall events (Beylich, 2003; Beylich \& Gintz, 2004). Precipitation from June to August accounts for about one quarter of the mean annual precipitation. The hydrological regime is nival, with runoff being limited to the period from end of May until October / November (Beylich, 2003). The bedrock is mainly composed of Cambro-Silurian mica-garnet schists and inclusions of marble (Beylich et al., 2004a). Intrusions of acidic granites can be found in the northern part of the valley. Regional deglaciation occurred about 8000 - 10000 yr BP (André, 1995). The drainage basin is dominated by large and flat plateau areas at $1300 \mathrm{~m}$ a.s.l., steep slopes which bound the glacially sculptured valley, and a flat valley floor situated between 950 and $1200 \mathrm{~m}$ a.s.l. (Fig. 4). The plateaux are best described as bare bedrock and boulder fields. The transition between slopes and plateaux is generally abrupt and, on the very steep, eastfacing slope, covered by perennial snow and ice patches. The lower part of the valley floor is dominated by a lake, Latnjajaure, and a series of moraine ridges. As based on extended geophysical mapping, regolith thicknesses are shallow and reach locally only a few meters (Beylich et al., 2004b). Main present soils are regosols and lithosols. The drainage basin area belongs to the mid-Alpine zone with a continuous and closed vegetation cover up to $1300 \mathrm{~m}$ a.s.l. comprising dwarf shrub heaths and Alpine meadows and bogs. The exact distribution of permafrost is not directly known but drilling outside the drainage basin at $1200 \mathrm{~m}$ a.s.l. indicates at least sporadic permafrost down to $80 \mathrm{~m}$ below the surface (see also Beylich et al., $2004 \mathrm{~b}$ ). There seems to be no ice-rich permafrost on the valley floor around $1000 \mathrm{~m}$ a.s.l. and on the lower parts of the gentle, west-facing valley slope (Beylich et al., 2004b). Denudative slope processes include chemical weathering and denudation, mechanical weathering, rock falls, boulder falls, ground avalanches, debris flows, translation slides, creep processes, solifluction, ploughing boulders, and slope wash. Slush flows occur in certain areas of the valley and deflation is active where the vegetation cover is disturbed or lacking. In the channels dissolved, suspended and bed load is transported. Direct human impact on the natural system is presently small and is limited to reindeer husbandry (extensive grazing), some hiking tourism and field research at the Latnjajaure Field Station (LFS) (Beylich et al., 2006b; Beylich, 2008).

\subsection{Aims of this geomorphologic research}

The major goals of this longer-term geomorphologic research are to: (1) analyse the rates and the spatio-temporal variability of denudative processes and sedimentary transfers within the three different small drainage basin geo-systems; (2) investigate the absolute and the relative importance of these different geomorphic processes; (3) quantify the mass transfers and sediment budgets for the entire three drainage basins; (4) analyse trends of relief development in the three different study areas.

\subsection{Approach and methods}

This field-based geomorphologic research focuses on quantifying rates of denudative processes, mass transfers and the sediment budgets in three small drainage basins in subArctic-oceanic Eastern Iceland and Arctic-oceanic Swedish Lapland. The collected data can be used for direct comparisons with other drainage basins worldwide (Beylich, 1999; 2000; 2002; Beylich \& Warburton, 2007; Beylich et al., 2007b; 2008; Lamoureux et al., 2007). 

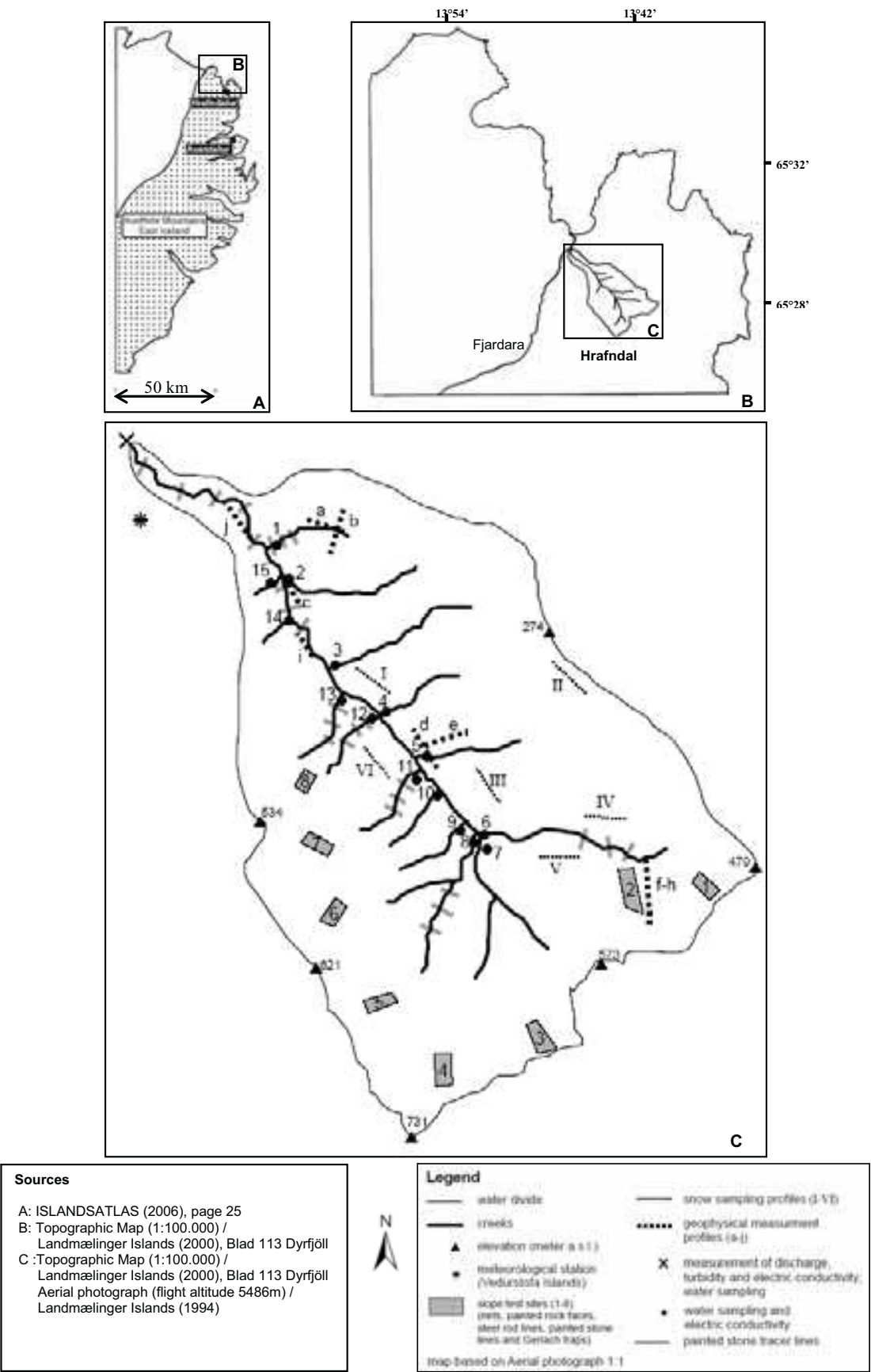

Fig. 5. Slope test sites, measuring points and instrumentation in the Hrafndalur drainage basin (eastern Iceland) 
By a combined, quantitative recording of the relevant denudative slope processes and the stream work information on the absolute and relative importance of the different denudative processes is collected. This kind of drainage basin - based quantitative study, applying unified and simple (i.e. reliable and low costs) geomorphic field methods and techniques in combination with selected advanced techniques (techniques for continuous surface processes monitoring and geophysical techniques), and being carried out in a larger number of different environments having different climatic, vegetational, human impact topographic, lithological / geological and tectonic features shall contribute to gain better understanding of the internal differentiation of different global environments (e.g. Barsch, 1984; 1986; Beylich; 2000; 2002; Beylich \& Warburton, 2007; Beylich et al., 2008; Beylich \& Kneisel, 2009). Furthermore, information on the controls of geomorphic processes, the quantitative role of extreme events for longer-term mass transfer rates and sediment budgets, the general intensity of geomorphic processes, and the relative importance of different geomorphic processes for slope and valley formation and recent relief and landform development in different environments shall be improved.

\section{Measurement of relevant denudative processes:}

A combination of surface processes monitoring, geomorphologic and geophysical mapping as well as further field observations and detailed photo documentation were used to analyse relevant denudative processes and sedimentary fluxes in the three drainage basins (Beylich, 2008; Beylich \& Kneisel, 2009). An adequate number of defined slope test sites within the three different drainage basins were selected after studying aerial photographs and after field investigations. The slope test sites differ with respect to slope form, aspect, elevation and local geographical setting and were selected to cover the complete range of different settings, which can be found within the three drainage basin systems. Figure 5 shows the location of slope test sites, measuring points and the instrumentation in Hrafndalur as an example. On the basis of detailed geomorphologic mapping (including mapping of areas being affected by certain processes) and process rates measured at the defined slope test sites and at defined measuring points (e.g. outlet of the drainage basin, etc.) process rates for the entire drainage basins were computed (inter- and extrapolations) using aerial photographs, DEM and GIS techniques in combination with fieldwork (Beylich, 2008; Beylich \& Kneisel, 2009).

\section{Rock falls and boulder falls:}

Rock falls and boulder falls were investigated by applying a combination of process monitoring and detailed photo documentation. At each investigated slope test site a net was installed with its longer side placed along the rock wall / face foot on the talus cone developed below clearly defined vertical rock walls/rock faces. The nets were efficient in collecting debris produced by mechanical weathering at the rock walls and transferred to the nets by primary and secondary rock falls. The collected debris was repeatedly quantified by weighing it with a portable field balance $\left(\left[\mathrm{kg} \mathrm{m}^{-2}\right],\left[\mathrm{kg} \mathrm{m}^{-2} \mathrm{yr}^{-1}\right]\right)$. Rock wall retreat rate $\left[\mathrm{mm} \mathrm{yr}^{-1}\right]$ was calculated by estimating the surface area of the defined and debris supplying rock face and relating it to the mass of debris accumulated below the rock face (Beylich et al., 2007a). The mass of accumulated debris smaller than ca. $1.0 \mathrm{~cm}$ in diameter was quantified with help of painted rock faces. At each slope test site with debris-supplying rock face two squares of $1 \mathrm{~m}^{2}$ were painted at the beginning of the investigations and repainted in each following year. Fine debris accumulated below the painted squares could be identified by colour on the debris and the total mass of fine debris was quantified by 
weighing the debris with a portable field balance. The total mass of fine debris was then related to the clearly defined source area of $1 \mathrm{~m}^{2}$ rock surface.

Boulder falls were investigated by detecting, mapping, counting and measuring fresh boulders accumulated below the boulder supplying rock walls. For detecting and mapping of fresh boulder falls a detailed photo documentation was carried out each summer taking photos from ground and from helicopter. The detailed boulder size measurements (a-, band c-axis) were carried out in field (Beylich, 2008; Beylich \& Kneisel, 2009).

\section{Avalanches:}

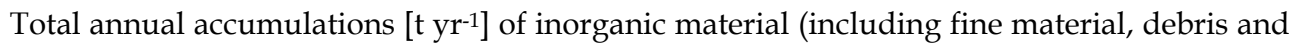
boulders) by avalanches were quantified by combining a detailed sampling, measuring and weighing of newly deposited material with an estimation of the entire affected deposition area at the valley slope and a detailed photo documentation of the entire valley slope systems. Newly accumulated and dried debris was weighted at defined $1-\mathrm{m}^{2}$ plots within the accumulation areas of avalanches and fine material was sampled for the quantification of the inorganic mass (burning of the material over $12 \mathrm{~h}$ in $550^{\circ} \mathrm{C}$ in the laboratory). The mapping of the entire deposition area as well as the detection and mapping of fresh boulder falls were carried out each summer during the investigation periods. Boulders were measured in field (a-, b-, c-axis) (Beylich, 2008; Beylich \& Kneisel, 2009).

\section{Debris flows and slides:}

Debris flows and debris slides were investigated by detailed and yearly repeated photo documentation of slopes both from ground and from helicopter. Both new and old traces of debris flows and debris slides were mapped. The volumes of transferred material as well as the transport distances were measured in field. Debris flows can be significant for transferring material from slope to main channel systems (Beylich \& Kneisel, 2009).

\section{Creep processes:}

Creep processes were analysed at the different slope test sites by detailed monitoring of movements of painted stone tracer lines and steel rod lines as well as depth-integrating peg lines (Beylich, 2008). At each slope test site lines with a number of painted stones were installed. Down-slope movements of all painted stones were measured each year in field. At each second location where a painted stone was placed a steel rod $(1.0 \mathrm{~cm}$ diameter $)$ was installed vertically $10 \mathrm{~cm}$ down into the ground. Down-slope movements of all steel rods as well as of depth-integrating peg lines (one per stone and steel rod line) were measured every year together with the measurements of movements of painted stones (Beylich, 2008).

\section{Chemical slope denudation:}

Chemical slope denudation was investigated by analysing water samples collected from small creeks and pipes on the slopes. Solute yields and chemical denudation rates were calculated based on measurements of atmospheric solute inputs to the drainage basin, runoff and solute concentrations in the main creeks (see below) (Beylich, 2008; Beylich \& Kneisel, 2009).

\section{Slope wash:}

Slope wash was studied by using Gerlach traps, which were installed at selected slope test sites. In addition, suspended sediment concentrations in small creeks draining the slope systems were analysed (Beylich et al., 2006b; Beylich, 2008; Beylich \& Kneisel, 2009). 


\section{Estimating the importance of deflation and aeolian deposition:}

The importance of deflation and aeolian deposition were estimated by using sediment traps and by analysing sediment concentrations in snow cores collected along defined profiles within the drainage basins (Beylich, 2008; Beylich et al., 2006b; Beylich \& Kneisel, 2009).

\section{Runoff and fluvial transport:}

Channel discharge was measured by continuous and year-round monitoring of water level using a pressure sensor (GLOBAL WATER) and collecting data every hour, in combination with propeller measurements at different selected water level stages using an Ott-propeller (model C2) during the field campaigns. Daily specific runoff [mm d-1] was calculated by dividing calculated daily discharge by the contributing drainage basin area (Beylich, 1999; Beylich \& Kneisel, 2009).

Fluvial suspended sediment and solute transport were analysed by combining continuous and year-round monitoring of turbidity and electric conductivity (GLOBAL WATER) with hourly readings with discrete water sampling ( 1 and 51 samples) during the field campaigns (Beylich \& Kneisel, 2009). Vertically integrated water samples were taken with $1000 \mathrm{ml}$ wide-necked polyethylene bottles. In addition, 11 water samples were also collected at different high-resolution time-intervals by automatic water samplers (ISCO). The samples were filtered at the field bases with a pressure filter and ash-free filter papers (Munktell quantitative filter papers). After the field campaigns the filter papers were burned $\left(550{ }^{\circ} \mathrm{C}\right)$ to analyse the concentrations of mineralogenic suspended solids [mg $\mathrm{l}^{-1}$. The estimation of annual solute yields was based on the relationship between electric conductivity and concentration of total dissolved solids (Beylich, 2008; Beylich \& Kneisel, 2009). The stability of creeks and channel stone pavements as well as the range of bed load transport was estimated by using painted stone tracer lines at selected creeks and channel stretches. In addition, fresh accumulations of debris/bed load were analysed by weighing of debris (portable field balance) and by a detailed measuring of the volumes of fresh deposits. The estimation of annual bedload transport rates presented in this chapter might include errors. Anyway, the repeated detailed mapping and analysis (two to three times per year) of selected channel stretches using photo documentation and the careful measuring of the volumes of fresh bedload deposits allows at least rough estimates (Beylich, 2008; Beylich \& Kneisel, 2009).

\section{Results and discussion}

On the basis of the process rates which were calculated for the Hrafndalur, Austdalur and Latnjavagge drainage basins after longer-term field studies (several years of process monitoring, mapping and observation) (Beylich, 2008; Beylich \& Kneisel, 2009) the absolute and the relative importance of present-day denudative processes in the entire catchments was estimated by the quantification of the mass transfers caused by the different processes. To allow direct comparison of the different processes, all mass transfers are shown as tonnes multiplied by meter per year [ $\left.\mathrm{t} \mathrm{m} \mathrm{yr}^{-1}\right]$, i.e. as the product of the annually transferred mass and the corresponding transport distance (see Jäckli, 1957; Rapp, 1960; Barsch, 1981; Beylich, 2000; 2008; Beylich \& Kneisel 2009). The mass transfers calculated for the Hrafndalur drainage basin are shown in Table 1.

It is stressed that these mass transfers are based on detailed process studies, extended mapping and process monitoring carried out over an eight-years period (2001 - 2009) (Beylich \& Kneisel, 2009). In computing the mass transfer caused by rock falls and boulder 


\begin{tabular}{|c|c|c|c|c|c|c|c|}
\hline & Process & $\begin{array}{l}\text { Volume } \\
{\left[\mathrm{m}^{3} \mathbf{y r}^{1}\right]}\end{array}$ & $\begin{array}{l}\text { Mass } \\
{\left[t \mathbf{y r}^{11}\right]}\end{array}$ & $\begin{array}{l}\text { Area } \\
{\left[\mathbf{k m}^{2}\right]}\end{array}$ & $\begin{array}{l}\text { Mass/Area } \\
{\left[\mathbf{t ~ k m}^{-2} \mathbf{y r}^{1]}\right.}\end{array}$ & $\begin{array}{c}\text { Average } \\
\text { movement }[\mathrm{m}]\end{array}$ & $\begin{array}{c}\text { Mass } \\
\text { transfer } \\
\text { [t m yr-1] }\end{array}$ \\
\hline \multirow{8}{*}{ 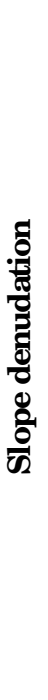 } & $\begin{array}{l}\text { Rockfalls and } \\
\text { boulder falls }\end{array}$ & 3196 & 7031 & 0.90 & 7812 & 50 & 351550 \\
\hline & Avalanches & 23 & 46 & 0.02 & 2300 & 235 & 10810 \\
\hline & Debris flows & 15 & 30 & 0.000062 & 483871 & 110 & 3300 \\
\hline & $\begin{array}{l}\text { Translational } \\
\text { slides }\end{array}$ & 5 & 10 & 0.000043 & 232558 & 26 & 263 \\
\hline & Creep & 450000 & 900000 & 1.8 & 500000 & 0.022 & 19800 \\
\hline & $\begin{array}{l}\text { Chemical } \\
\text { denudation }\end{array}$ & 92 & 203 & 7 & 29 & 400 & 81200 \\
\hline & $\begin{array}{l}\text { Mechanical } \\
\text { fluvial } \\
\text { denudation }\end{array}$ & 67 & 133 & 7 & 19 & 400 & 53200 \\
\hline & Deflation & 0.02 & 0.04 & 5 & 0.008 & 400 & 16 \\
\hline \multirow{3}{*}{ 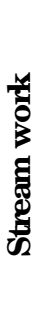 } & $\begin{array}{l}\text { Solute } \\
\text { transport }\end{array}$ & 92 & 203 & 7 & 29 & 1750 & 355250 \\
\hline & $\begin{array}{l}\text { Suspended } \\
\text { sediment } \\
\text { transport }\end{array}$ & 67 & 133 & 7 & 19 & 1750 & 232750 \\
\hline & $\begin{array}{l}\text { Bedload } \\
\text { transport }\end{array}$ & 81 & 178 & 0.18 & 989 & 875 & 155750 \\
\hline
\end{tabular}

Table 1. Annual mass transfers by different denudative processes in Hrafndalur (eastern Iceland), as based on investigations carried out from 2001 until 2009

falls, the following assumptions were made: a total debris-supplying rock wall surface of 0.9 $\mathrm{km}^{2}$, a mean annual rock wall retreat rate of $3.55 \mathrm{~mm} \mathrm{yr}^{-1}$, an average transport distance of $50 \mathrm{~m}$ and an average rock density of 2.2 (Beylich et al., 2007a; Beylich \& Kneisel, 2009). The material transported and deposited by avalanches was presumed to have an average density of 2.0 (Beylich \& Kneisel, 2009). Calculating the mass transfer caused by creep was led by the following assumptions: an affected surface of $1.8 \mathrm{~km}^{2}$, an average movement rate of $0.022 \mathrm{~m}$ $\mathrm{yr}^{-1}$ in a $0.25 \mathrm{~m}$ thick layer, and a medium density of 2.0 (Beylich \& Kneisel, 2009). In contrast to the other denudative processes, chemical denudation affects the total surface of the slope systems. The transport distance of $400 \mathrm{~m}$ is about half the medium distance between water divide and main channel. The transport distance of $1750 \mathrm{~m}$ for fluvial solute and suspended sediment transport is about half the distance between the water divide opposite to the drainage basin outlet and the outlet. The presented estimation of annual 
mass transfers might include some errors. Anyway, the scale of the calculated mass transfers and the relative importance of the different processes should be correct.

Ranking the different processes according to their annual mass transfers shows that stream work dominates over slope denudation, with fluvial solid transport, including both suspended sediment transport plus bed load transport, being more important than fluvial solute transport. Rock falls plus boulder falls are clearly the most important slope process, followed by chemical denudation. As a result, according to their relative importance, the different processes can be ranked as follows (see Table 1):

1. Fluvial suspended sediment plus bed load transport

2. Fluvial solute transport

3. Rock falls plus boulder falls

4. Chemical slope denudation

5. Mechanical fluvial slope denudation (slope wash)

6. Creep processes

7. Avalanches

8. Debris flows

9. Translation slides

10. Deflation

With respect to the temporal variability of process intensities and/or process frequencies the main snow melt period (April - June), autumn showing heavy rainfalls (especially September - November) and intensive thaw periods in winter can be pointed out as periods with comparably high activity of denudative processes.

The combined quantitative analysis of the slope and channel systems, or of slope and stream work respectively, allows statements on trends of relief development in Hrafndalur. By the retreat of rock faces and the connected formation of talus cones located below these rock faces, slope processes cause a gradually valley widening in the Hrafndalur drainage basin (Fig. 2). The valley floor is characterised by a fluvial throughput of material delivered from the slope systems. Coupling between slope and fluvial systems exists especially in the upper parts of the drainage basin where talus cones reach down into the channels. Altogether material transfer from slopes to channels via (i) avalanches, (ii) debris flows, (iii) creep processes and (iv) fluvial transfers is intensive, with material being fluvially exported from the drainage basin without longer-term storage within the main channels.

Geoelectrical surveys in the upper parts of Hrafndalur (Beylich \& Kneisel, 2009) documented larger volumes of debris with thickness of talus cones of about $15-20 \mathrm{~m}$. The geophysical surveys were also aimed to infer Holocene valley filling and regolith thickness in the lower parts of the drainage basin using geoelectrical techiquess. A detected generally high conductivity within the subsurface can be related to a high porosity and high water storage capacity of the weathered rhyolites. Due to indistinct resistivity contrasts the differentiation between regolith and bedrock is made difficult. It seems that the boundary between bedrock and overlying regolith / valley filling is not reached with the applied survey length, which was limited to $175 \mathrm{~m}$ due to $5 \mathrm{~m}$ spacing of the multi-electrode cable. This indicates that the depth of the boundary between bedrock and regolith / valley filling is larger than $25 \mathrm{~m}$. The high porosity of the rhyolite and the large regolith thicknesses found in lower parts of Hrafndalur explain the comparably high rates of chemical slope denudation, with the values in this rhyolite area clearly exceeding the rates of chemical slope denudation in basalt areas of Austfirđir (see Tables 1 and 2) (Beylich, 2000; 2003; 2007; Beylich \& Kneisel, 2009). The larger volumes of Postglacial valley fillings in the lower part of Hrafndalur indicate high rates of fluvial solid transport during the Holocene. 
Due to the comparably high mechanical weathering and sedimentary transfer rates, Postglacial modification of the Pleistocene glacially formed landscape is clearly more advanced than in the extended basalt areas of Austfirðir. Anyway, due to the short time since the deglaciation (about $8000 \mathrm{yr}$ ) there has been no adjustment of the glacially formed landforms to the geomorphic processes, which have been operating under Holocene climates until today.

Comparing the results from Hrafndalur with data collected in the Austdalur drainage basin, located south from Hrafndalur in the basalt area of Austfirðir (Fig. 1, Table 2) (see also Beylich, 1999; 2000; 2003; 2007) reveals significant differences between the two drainage basins. Both areas are very similar with respect to climate, vegetation, human impact and topography, but significantly different with respect to lithology.

\begin{tabular}{|c|c|c|c|c|c|c|c|}
\hline & Process & $\begin{array}{l}\text { Volume } \\
{\left[\mathbf{m}^{3} \mathbf{y r}^{-1}\right]}\end{array}$ & $\begin{array}{l}\text { Mass } \\
{\left[t \mathbf{y r}^{1]}\right]}\end{array}$ & $\begin{array}{l}\text { Area } \\
{\left[\mathbf{k m}^{2}\right]}\end{array}$ & $\begin{array}{l}\text { Mass/Area } \\
{\left[\mathbf{t ~ k m}^{-2} \mathbf{y r}^{1]}\right.}\end{array}$ & $\begin{array}{c}\text { Average } \\
\text { movement }[\mathrm{m}]\end{array}$ & $\begin{array}{c}\text { Mass } \\
\text { transfer } \\
{\left[\text { t m yr } \mathbf{y r}^{-1}\right]}\end{array}$ \\
\hline \multirow{8}{*}{ 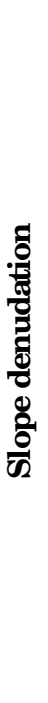 } & $\begin{array}{l}\text { Rockfalls and } \\
\text { boulder falls }\end{array}$ & 149 & 373 & 1.50 & 249 & 100 & 37300 \\
\hline & Avalanches & 73 & 146 & 0.04 & 3650 & 290 & 42340 \\
\hline & Debris flows & 12 & 24 & 0.000051 & 470588 & 80 & 1920 \\
\hline & $\begin{array}{l}\text { Translational } \\
\text { slides }\end{array}$ & 1.5 & 3 & 0.000032 & 93750 & 14 & 42 \\
\hline & Creep & 1080000 & 1944000 & 5.4 & 360000 & 0.01 & 19440 \\
\hline & $\begin{array}{l}\text { Chemical } \\
\text { denudation }\end{array}$ & 74 & 184 & 23 & 8 & 750 & 138000 \\
\hline & $\begin{array}{l}\text { Mechanical } \\
\text { fluvial } \\
\text { denudation }\end{array}$ & 439 & 966 & 23 & 42 & 750 & 724500 \\
\hline & Deflation & 0.06 & 0.12 & 17 & 0.007 & 750 & 90 \\
\hline \multirow{3}{*}{ 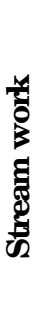 } & \begin{tabular}{|l} 
Solute \\
transport
\end{tabular} & 74 & 184 & 23 & 8 & 2800 & 515200 \\
\hline & $\begin{array}{l}\text { Suspended } \\
\text { sediment } \\
\text { transport }\end{array}$ & 439 & 966 & 23 & 42 & 2800 & 2704800 \\
\hline & $\begin{array}{l}\text { Bedload } \\
\text { transport }\end{array}$ & 19 & 48 & 0.4 & 120 & 500 & 24000 \\
\hline
\end{tabular}

Table 2. Annual mass transfers by different denudative processes in Austdalur (eastern Iceland), as based on investigations carried out from 1996 until 2009 
The rhyolites in Hrafndalur are clearly less resistant than the basalts found in Austdalur (Beylich et al., 2007a), and Postglacial modification of the Pleistocene glacial landforms is only very little in Austdalur but significant in Hrafndalur (Beylich, 2000; 2007; Beylich \& Kneisel, 2009). The high level of coupling between slope and channel systems given in Hrafndalur does not exist to that extent in Austdalur, resulting in a clearly lower relevance of bed load transport in Austdalur as compared to Hrafndalur. The intensive coupling between slope and fluvial systems in Hrafndalur, with significant transfers of material from the slopes into main channels, is strongly connected to the Holocene development of extended talus cones, which partly reach and directly feed into the main channels. Compared to that, slope systems in Austdalur are only connected to the main channels via small creeks draining the slope systems (Beylich, 1999; 2000), and slope and channel systems are largely decoupled in this drainage basin.

Suspended sediment yields in Hrafndalur are clearly lower than in Austdalur and chemical denudation dominates over suspended sediment yields in the Hrafndalur drainage basin whereas suspended sediment yields clearly dominate over chemical denudation rates in Austdalur (Tables 1 and 2). These differences between the two areas can be explained by the significantly higher porosity and connected higher infiltration and water storage capacity of the rhyolites in Hrafndalur as compared to the basalts in Austdalur (see above, Beylich et al., 2007a; Beylich \& Kneisel, 2009).

According to the mass transfers, which were computed after thirteen years (1996 - 2009) of geomorphic process studies in Austdalur, the different denudative processes in the Austdalur drainage basin can be ranked as follows according to their relative importance (see Table 2):

1. Fluvial suspended sediment plus bedload transport

2. Fluvial solute transport

3. Mechanical fluvial slope denudation (slope wash)

4. Chemical denudation

5. Avalanches

6. Rock falls plus boulder falls

7. Creep processes

8. Debris flows

9. Deflation

10. Translation slides

The mass transfers calculated for the Latnjavagge drainage basin in northern Swedish Lapland are provided in Table 3.

It has to be stressed that these mass transfers are based on detailed geomorphologic process studies, extended mapping and process monitoring which were carried out over a ten-years period (1999 - 2009), and that the values shown in Table 3 are excluding the geomorphic effects of a rare rainfall event that happened on July 20-21, 2004 (Beylich \& Sandberg, 2005) and of a mega slush flow event that occurred in May 1999. The role of these extreme events is further discussed below. In computing the mass transfers caused by rock- and boulder falls, the following assumptions were made: a total debris-supplying rock wall and rock ledge surface of $3.15 \mathrm{~km}^{2}$, a mean annual rock wall retreat rate of $0.44 \mathrm{~mm} \mathrm{yr}^{-1}$, an average transport distance of $7.5 \mathrm{~m}$ and an average rock density of 2.5. Also the material transported and deposited by ground avalanches was presumed to have an average density of 2.5 (Beylich, 2008). Calculating the mass transfer caused by creep and solifluction was led by the following assumptions: an affected surface of $2.8 \mathrm{~km}^{2}$, an average movement rate of $0.003 \mathrm{~m}$ 
$\mathrm{yr}^{-1}$ in a $0.3 \mathrm{~m}$ thick layer, and a medium material density of 2.0 (Beylich, 2008). In contrast to the other denudative processes, chemical denudation affects the total surface of the slope systems (Beylich et al., 2004a; 2004b). The transport distance of $500 \mathrm{~m}$ is about half the medium distance between water divide and main channel. The transport distance of $2300 \mathrm{~m}$ for fluvial solute transport is about half the medium distance between the water divide opposite to the outlet and the drainage basin outlet. Mass transfers by fluvial suspended sediment transport and fluvial bedload transport are based on an average movement of 1400 $\mathrm{m}$, which is about half the medium distance between water divide and inlet Latnjajaure (lake), for suspended sediments and $250 \mathrm{~m}$, based on monitoring of tracer movements, for bed load (Beylich et al., 2006b; Beylich, 2008).

\begin{tabular}{|c|c|c|c|c|c|c|c|}
\hline & Process & $\begin{array}{l}\text { Volume } \\
{\left[\mathbf{m}^{3} \mathbf{y} \mathbf{r}^{1]}\right]}\end{array}$ & $\begin{array}{l}\text { Mass } \\
{\left[t \mathbf{y r}^{1]}\right]}\end{array}$ & $\begin{array}{l}\text { Area } \\
{\left[\mathbf{k m}^{2}\right]}\end{array}$ & $\begin{array}{l}\text { Mass/Area } \\
{\left[\mathbf{t ~ k m}^{-2} \mathbf{y r}^{1]}\right.}\end{array}$ & $\begin{array}{c}\text { Average } \\
\text { movement }[\mathrm{m}]\end{array}$ & $\begin{array}{c}\text { Mass } \\
\text { transfer } \\
\text { [t m yr-1] }\end{array}$ \\
\hline \multirow{9}{*}{ 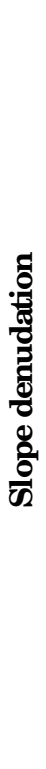 } & $\begin{array}{l}\text { Rockfalls and } \\
\text { boulder falls }\end{array}$ & 1377 & 3441 & 3.15 & 1092 & 7.5 & 25808 \\
\hline & Avalanches & 27 & 68 & 0.02 & 3400 & 150 & 10200 \\
\hline & Debris flows & 3 & 6 & 0.000016 & 375000 & 47 & 279 \\
\hline & $\begin{array}{l}\text { Translational } \\
\text { slides }\end{array}$ & 1.5 & 3 & 0.000022 & 136364 & 3.7 & 11 \\
\hline & Creep & 840000 & 1680000 & 2.8 & 600000 & 0.003 & 5040 \\
\hline & $\begin{array}{l}\text { Chemical } \\
\text { denudation }\end{array}$ & 22 & 44 & 9 & 4.9 & 500 & 22000 \\
\hline & $\begin{array}{l}\text { Mechanical } \\
\text { fluvial } \\
\text { denudation }\end{array}$ & 10.5 & 21 & 9 & 2.4 & 500 & 10500 \\
\hline & Deflation & 0.005 & 0.01 & 2.5 & 0.004 & 500 & 5 \\
\hline & Slush flows & 13 & 32 & 0.000097 & 329897 & 110 & 3520 \\
\hline \multirow{3}{*}{ 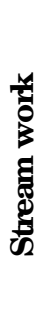 } & $\begin{array}{l}\text { Solute } \\
\text { transport }\end{array}$ & 22 & 44 & 9 & 4.9 & 2300 & 101200 \\
\hline & $\begin{array}{l}\text { Suspended } \\
\text { sediment } \\
\text { transport }\end{array}$ & 10.5 & 21 & 9 & 2.4 & 1400 & 29400 \\
\hline & \begin{tabular}{|l} 
Bedload \\
transport
\end{tabular} & 3 & 8 & 0.04 & 200 & 250 & 2000 \\
\hline
\end{tabular}

Table 3. Annual mass transfers by different denudative processes in Latnjavagge (Swedish Lapland), as based on investigations carried out from 1999 until 2009 
Fluvial solute transport clearly dominates over fluvial sediment transport. Ranking the different processes according to their annual mass transfers shows that stream work dominates over slope denudation, with fluvial solute transport being clearly the most important process. Rock falls plus boulder falls is the most important factor in slope denudation, followed by chemical denudation. As a result, according to their relative importance, the different processes can be ranked as follows (see Table 3):

1. Fluvial solute transport

2. Fluvial suspended sediment transport plus fluvial bedload transport

3. Rock falls plus boulder falls

4. Chemical slope denudation

5. Mechanical fluvial slope denudation (slope wash)

6. Avalanches

7. Creep processes and solifluction

8. Slush flows

9. Debris flows

10. Translation slides

11. Deflation

With respect to the temporal variability of process intensities and/or process frequencies the main snow melt period (late May - June/July) which is characterised by high runoff, increased fluvial transport, slush flow activity, ground avalanches and rock and boulder falls as well as August which is the month showing the highest frequency of extreme rainfall events (Beylich, 2003; Beylich \& Gintz, 2004) triggering debris flows, translation slides, secondary rock falls, boulder falls, peak runoff and increased fluvial transport, can be pointed out as periods with comparably high activity. The period from late October until early May is compared to that characterised by only very little (single avalanches) or no activity (Beylich et al., 2006b; Beylich, 2008).

On July $20^{\text {th }}-21^{\text {st }}, 2004$, an extreme rainfall event, with $58.4 \mathrm{~mm}$ of rain within $24 \mathrm{~h}$ and 71.7 $\mathrm{mm}$ of rain within $48 \mathrm{~h}$ as measured at the weather station of the Latnjajaure Field Station (LFS), occurred (Beylich \& Sandberg, 2005). This extreme rainfall event is considered a "rare event" (Beylich, 2003), which caused extreme peak runoff in the fluvial systems of the Abisko mountain area and significant damage to the road between Abisko and Kiruna (Beylich \& Sandberg, 2005). The rare rainfall event triggered high sediment transfers on the slopes and in the fluvial systems of the Latnjavagge drainage basin, and the quantified mass transfers at only one day during this rare rainfall event exceeded the mean annual mass transfers, calculated for the nine-years period 1999 - 2008 (and excluding the rare rainfall event of July 2004), by several times (see Beylich \& Sandberg, 2005; Beylich et al., 2006b). The rare rainfall event caused several debris flows, translation slides, boulder falls, secondary rock falls, locally very high slope wash, bank erosion in creeks above the Latnjajaure delta and high suspended sediment and bed load transport in creeks. Table 2 in Beylich \& Sandberg (2005, page 415) provides mass transfers [ $\mathrm{t} \mathrm{m}$ ] by debris flows, translation slides and fluvial debris transport in creeks and channels, which were caused in different parts of the Latnjavagge drainage basin by the July $20^{\text {th }}-21^{\text {st }}, 2004$ rainfall event. The mass transfers triggered by the rare event can be discussed in direct comparison with the mean annual mass transfers calculated for the period 1999 - 2009 (and excluding the rare rainfall event) (Table 3). The mass transfer by debris flows, which were triggered during the rare rainfall event was $2030 \mathrm{t} \mathrm{m}$ in the entire Latnjavagge drainage basin which is 7.3 times higher than the mean annual mass transfer by debris flows $(279 \mathrm{t} \mathrm{m})$. It has to be noted that the annual 
mass transfers by debris flows have clearly increased after the July 2004 event which is also reflected in significantly higher annual mean mass transfer for the ten-years period 1999 $2009(279 \mathrm{t} \mathrm{m})$ as compared to the annual mean mass transfer for the five-years period 1999 - $2004(212 \mathrm{t} \mathrm{m})$. The mass transfer by translation slides which were triggered during the rare event reached $2446 \mathrm{t} \mathrm{m}$ in the entire drainage basin which is 222.4 times higher than the mean annual mass transfer by slides $(11 \mathrm{t} \mathrm{m})$. It is again necessary to stress that also the annual mass transfers caused by translation slides have clearly increased after the July 2004 rare rainfall event, which is documented by a significantly higher mean annual mass transfer for the ten-years period $1999-2009(11 \mathrm{t} \mathrm{m})$ as compared to the five-years period 1999 - $2004(2.5 \mathrm{t} \mathrm{m})$. The total mass transfer by fluvial debris transport in creeks and channels during the rare rainfall event was $7480 \mathrm{t} \mathrm{m}$ which is 16.9 times higher than the corresponding mean annual mass transfer within the entire Latnjavagge drainage basin quantified to be $444 \mathrm{t} \mathrm{m}$ for the period 1999 - 2004 (Beylich \& Sandberg, 2005).

During the rare event the mass transfer by fluvial debris transport in creeks and channels (7480 $\mathrm{t} \mathrm{m}$ ) had clearly the highest relative importance, followed by mass transfers by slides $(2446 \mathrm{t} \mathrm{m})$ and debris flows $(2030 \mathrm{t} \mathrm{m})$. Compared to that, the mean annual mass transfers (excluding the July 20-21, 2004 event) show again a relative dominance of fluvial debris transport in creeks, but are followed by debris flows whereas translation slides are of only minor importance.

During the rare rainfall event the mass transfers caused by debris flows, translation slides and fluvial debris transport as well as suspended sediment transport were several times higher than the mean annual mass transfers.

The mega slush flow event of May 1999 caused a mass transfer, which was about 107 times higher than the mean annual total mass transfer caused by several small slush flows between 1999 and 2009.

Both the rare rainfall event of July 20th $-21^{\text {st }}, 2004$ and the mega slush flow event of May 1999 underline the high importance of rare events for the calculation of longer-term sedimentary budgets. Both rare events also reveal the difficulties of defining an adequate length for monitoring programmes (Beylich \& Sandberg, 2005; Beylich \& Warburton, 2007).

Comparing the results from Latnjavagge with data collected in other cold environment drainage basins in northern Sweden shows some similarities but also some significant differences. Rapp (1960) stressed in his seminal study of denudation and slope development in Kärkevagge, northernmost Swedish Lapland, the high importance of chemical weathering and denudation and his work stands out as the study which opened awareness of chemical denudation in cold environments. His findings for Kärkevagge and a high relative importance of chemical weathering and denudation were confirmed by later investigations carried out in this valley (e.g. Dixon et al., 2008) and have also been postulated for other cold climate environments (see e.g. French, 1996). Compared to that, and in accordance with findings in Latnjavagge, slope wash processes are of only little importance in Kärkevagge (Rapp, 1960; Strömquist \& Rehn, 1981). A significant difference between the mass transfers calculated for Latnjavagge and the mass transfers published by Rapp (1960) is the high importance of slides and debris flows in Kärkevagge. The high importance of slides and debris flows found by Rapp (1960) is mainly based on mass transfers which were triggered by a rare rainfall event with $107 \mathrm{~mm}$ in $24 \mathrm{~h}$ and $175 \mathrm{~mm}$ in $72 \mathrm{~h}$ in October 1959. This rare event occurred at the end of Rapp`s 9-years investigation period (1952 - 1960) and the mean annual mass transfers caused by slides and debris flows as calculated by Rapp for his 9-years investigation period might actually be too high, given 


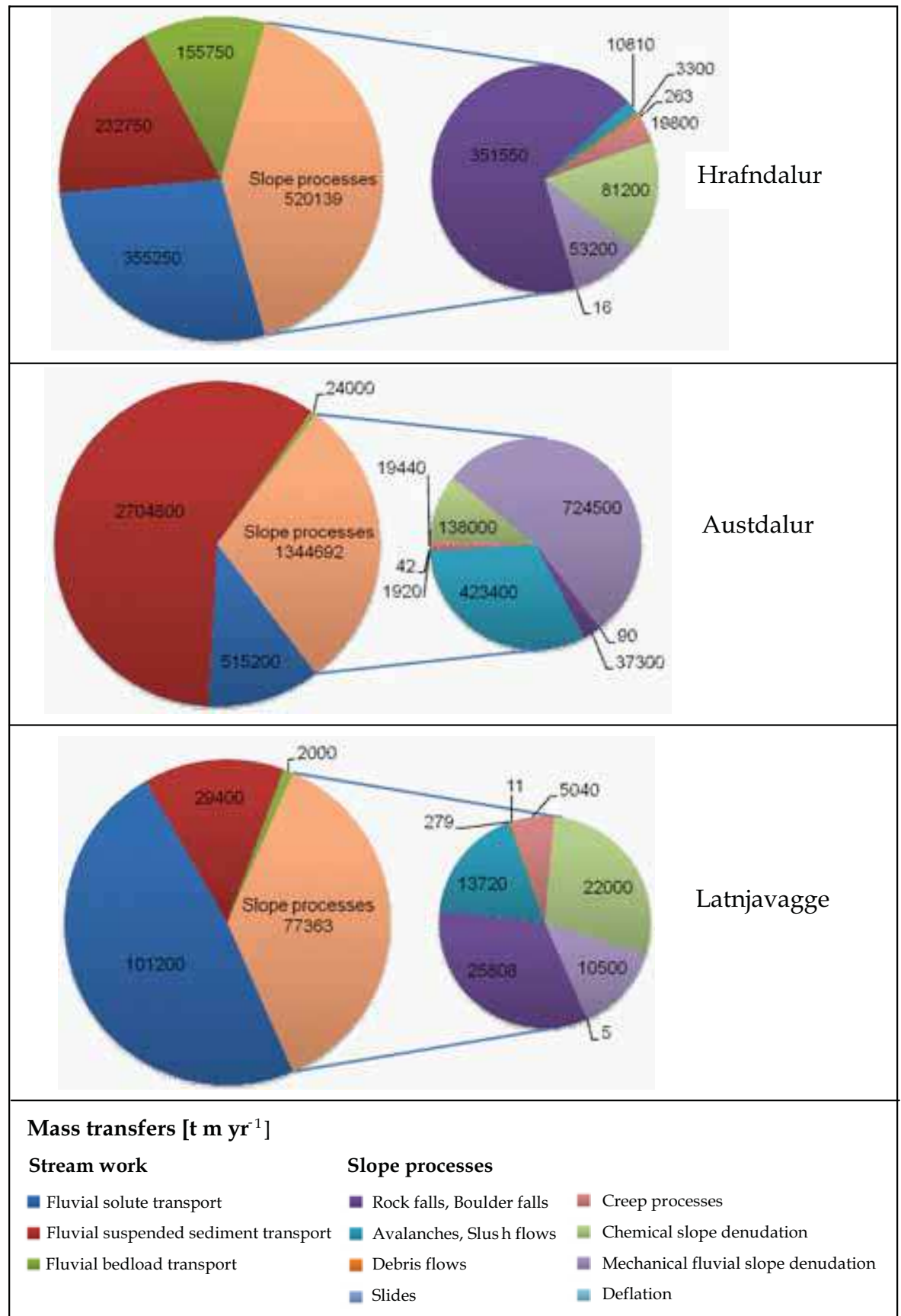

Fig. 6. Annual mass transfers in Hrafndalur (eastern Iceland), Austdalur (eastern Iceland) and Latnjavagge (Swedish Lapland) 
the long recurrence intervals of such rare rainfall events in northernmost Swedish Lapland (Beylich, 1999; 2003; see also French, 1996). The problem of defining an adequate length of monitoring programmes becomes, as in Latnjavagge with respect to the rare rainfall event of July 2004 and the mega slush flow event of May 1999, again obvious (Beylich \& Sandberg, 2005).

As in eastern Iceland, fluvial transport dominates over slope processes in Swedish Lapland but, differently from eastern Iceland, in Swedish Lapland fluvial solute transport dominates over fluvial sediment transport (Beylich, 2009; Beylich \& Kneisel, 2009). This difference is partly due to human impact and the connected disturbance and partly removal of the vegetation cover in eastern Iceland.

The conducted combined quantitative analysis of the slope systems and channel systems, or of slope denudation and stream work, respectively, allows also statements on current trends of relief development in Latnjavagge. By the retreat of rock walls and rock ledges and the continued formation of talus cones located below the rock walls and rock ledges, slope processes cause also in the Latnjavagge drainage basin a general valley widening (Fig. 4). The valley floor is characterised by a fluvial throughput of material above the delta of Latnjajaure, net accumulation of material in the delta of Latnjajaure and in the lake and a moderate fluvial down cutting between the outlet of Lake Latnjajaure and the outlet of the entire Latnjavagge drainage basin. Coupling between slope systems and fluvial systems exists only to a limited extend (i) via slush flows in defined areas within the valley as well as (ii) via ground avalanches at a short main channel stretch directly above the delta of Latnjajaure. Altogether, Postglacial modification of the glacial relief is little (Fig. 4). Due to the also in Swedish Lapland short time since the deglaciation $(8000-10000 \mathrm{yr})$ and the altogether low intensity of the active denudative surface processes, until today, there has been no adjustment of the Pleistocene glacial landforms to the geomorphic processes which have been operating until present under the Holocene climates.

As based on the presented quantitative investigations, in all selected study areas in subArctic oceanic eastern Iceland and Arctic oceanic Swedish Lapland the intensity of contemporary denudative processes and mass transfers is altogether rather low which is in opposition to the earlier postulated (e.g. Büdel, 1981; Tricart, 1970) high intensity of geomorphic processes in cold climate environments, with these earlier statements have only being based on purely qualitative descriptions.

A direct comparison of the mass transfers within the three investigated drainage basins (Fig. 6., see also Tables 1 - 3) summarises that there are differences between process intensities and the relative importance of different denudative processes within the study areas in eastern Iceland and Swedish Lapland.

The major controls of these detected differences are

i. Climate:

The higher annual precipitation along with the larger number of extreme rainfall events and the higher frequency of snowmelt and rainfall generated peak runoff events in eastern Iceland as compared to Swedish Lapland leads to higher mass transfers. All three study areas are located in cold regions and projected climate change is expected to alter melt season duration and intensity, along with an increased number of extreme rainfall events, total annual precipitation and the balance between snowfall and rainfall. In addition, changes in the thermal balance are expected to reduce the extent of permafrost and seasonal ground frost and increase active layer depths (ACIA, 2004). Looking at the existing differences between Hrafndalur / Austdalur (eastern Iceland) 
and Latnjavagge (Swedish Lapland) it seems obvious that the projected changes in climate will cause significant changes of mass transfers,

ii. Lithology:

The low resistance of the rhyolites in Hrafndalur causes especially high weathering rates and connected mass transfers in this drainage basin. Due to the lower resistance of the rhyolites as compared to the basalts found in Austdalur Postglacial modification of the glacially formed relief is clearly further advanced in Hrafndalur as compared to Austdalur,

iii. Relief:

The greater steepness of the Icelandic drainage basin leads to higher mass transfers here as compared to Latnjavagge,

iv. Vegetation cover:

The significant disturbance of the vegetation cover by direct human impacts in Hrafndalur / Austdalur (eastern Iceland) causes higher mass transfers by slope wash here whereas restricted sediment availability is a major reason for lower mass transfers in Latnjavagge (Swedish Lapland).

\section{Conclusion}

By the combined, quantitative recording of the relevant denudative slope processes and stream work in three selected drainage basins, information on the absolute and relative importance of the different denudative processes has been collected. The selected drainage basin - based approach (Beylich, 1999; 2000; 2002; 2008; Beylich \& Kneisel, 2009) seems to be effective for analysing the sediment budget and trends of Postglacial relief development in selected study areas with given environmental settings. More studies to the present one, carried out with unified geomorphologic field methods (Beylich \& Warburton, 2007; Beylich et al., 2006a; 2008; Lamoureux et al., 2007) in environments having different climatic, vegetational, human impact, topographic, lithological / geological and tectonic features will help to gain better understanding of the internal differentiation of different global environments (see e.g. Barsch, 1984; 1986; Beylich et al., 2006a; 2008). Furthermore, additional information on the control mechanisms of processes, the role of extreme geomorphic events for longer-term mass transfers and sediment budgets, the general intensity of geomorphic processes and mass transfers, and the relative importance of different processes for slope and valley formation and relief development under different environmental conditions can be collected. Direct comparisons of drainage basins and the application of the Ergodic principle of space-for-time substitution will improve the possibilities to model relief development as well as possible effects of projected climate change.

\section{References}

ACIA (2004). Impacts of a warming Arctic: Arctic Climate Impact Assessment. ACIA Overview Report. Arctic Climate Impact Assessment. Cambridge University Press.

André, M.-F. (1995). Postglacial microweathering of granitic roches mountonnees in Northern Scandinavia. In: Slaymaker, O. (Ed.), Steepland Geomorphology, pp. 103127, Wiley, London.

Ballantyne, C.K. (2002). Paraglacial Geomorphology. Quaternary Science Reviews, 21, pp. 1935-2017. 
Barsch, D. (1981). Studien zur gegenwartigen Geomorphodynamik im Bereich der Oobloyah Bay, N-Ellesmere Island, N.W.T., Kanada. Heidelberger Geographische Arbeiten, 69, pp. 123-161.

Barsch, D. (1984). Geomorphologische Untersuchungen zum periglazialen Milieu polarer Geosysteme. Zeitschrift für Geomorpologie. N.F., Suppl.-Bd., 50, pp. 107-116.

Barsch, D. (1986). Forschungen in Polargebieten. Heidelberger Geowissenschaftliche Abhandlungen, 6, pp. 33-50.

Barsch, D. (1993). Periglacial geomorphology in the 21st century. Geomorphology, 7, pp. 141163.

Barsch, D.; Gude, M.; Mäusbacher, R.; Schukraft, G. \& Schulte, A. (1994). Recent fluvial sediment budgets in glacial and periglacial environments, NW Spitsbergen. Zeitschrift für Geomorphologie, Suppl., 97, pp. 111-122.

Becht, M. (1995). Untersuchungen zur aktuellen Reliefentwicklung in alpinen Einzugsgebieten. Münchener Geographische Abhandlungen, A47. München.

Beylich, A.A. (1999). Hangdenudation und fluviale Prozesse in einem subarktisch-ozeanisch geprägten, permafrostfreien Periglazialgebiet mit pleistozäner Vergletscherung Prozessgeomorphologische Untersuchungen im Bergland der Austfirđir (Austdalur, Ost-Island). Berichte aus der Geowissenschaft, Aachen. 130pp.

Beylich, A.A. (2000). Geomorphology, sediment budget, and relief development in Austdalur, Austfirdir, East Iceland. Arctic, Antarctic, and Alpine Research, 32, 4, pp. 466-477.

Beylich, A.A. (2002). Sediment budgets and relief development in present periglacial environments - a morphosystem analytical approach. Hallesches eahrbuch für Geowissenschaften, A24, pp. 111-126.

Beylich, A.A. (2003). Present morphoclimates and morphodynamics in Latnjavagge, the northern Swedish Lapland and Austdalur, East Iceland. ebkull, 52, pp. 33-54.

Beylich, A.A. (2007). Quantitative studies on sediment fluxes and sediment budgets in changing cold environments - potential and expected benefit of coordinated data exchange and the unification of methods. Landform Analysis, 5: pp. 9-10.

Beylich, A.A. (2008). Mass transfers, sediment budget and relief development in the Latnjavagge catchment, Arctic-oceanic Swedish Lapland. Zeitschrift für Geomorphologie. N.F., 52, 1, pp. 149-197.

Beylich, A.A. (2009). Chemical and mechanical fluvial denudation rates in cold environments - Comparison of denudation rates from three catchments in subArctic Eastern Iceland, sub-Arctic Finnish Lapland and Arctic Swedish Lapland. ‘bkul, 59, pp. 19-32.

Beylich, A.A.; Etienne, S.; Etzelmüller, B.; Gordeev, V.V.; Käyhkö, J.; Rachold, V.; Russell, A.J.; Schmidt, K.-H.; Sæmundsson, P.; Tweed, F.S. \& Warburton, J. (2006a). The European Science Foundation (ESF) Network SEDIFLUX - An introduction and overview. Geomorphology, 80, pp. 3-7.

Beylich, A.A. \& Gintz, D. (2004). Effects of high-magnitude/low-frequency fluvial events generated by intense snowmelt or heavy rainfall in Arctic periglacial environments in northern Swedish Lapland and northern Siberia. Geografiska Annaler, 86A, pp. 11-29.

Beylich, A.A.; Gustavsson, M. \& Kolstrup, E. (2007a). Experimental weathering of selected non-calcareous rock types under wet/moist conditions. Zeitschrift für Geomorphologie N.F., 51, 1, pp. 1-26. 
Beylich, A.A. \& Kneisel, Ch. (2009). Sediment budget and relief development in Hrafndalur, subarctic oceanic eastern Iceland. Arctic, Antarctic and Alpine Research, 41, 1, pp. 3-17.

Beylich, A.A.; Kolstrup, E.; Thyrsted, T. \& Gintz, D. (2004a). Water chemistry and its diversity in relation to local factors in the Latnjavagge drainage basin, Arcticoceanic Swedish Lapland. Geomorphology, 58, pp. 125-143.

Beylich, A.A.; Kolstrup, E.; Thyrsted, T.; Linde, N.; Pedersen, L.B. \& Dynesius, L. (2004b). Chemical denudation in Arctic-alpine Latnjavagge (Swedish Lapland) in relation to regolith as assessed by radio magnetotelluric-geophysical profiles. Geomorphology, 57, pp. 303-319.

Beylich, A.A.; Lamoureux, S.F. \& Decaulne, A. (2007b). Coordinated quantitative studies on sediment fluxes and sediment budgets in changing cold environments - examples from three SEDIBUD key test areas in Canada, Iceland and Norway. Landform Analysis, 5, pp. 11-12.

Beylich, A.A.; Lamoureux, S.F. \& Decaulne, A. (2008). The global I.A.G./A.I.G. SEDIBUD (Sediment Budgets in Cold Environments) programme: Introduction and overview. Norsk Geografisk Tidsskrift - Norwegian eburnal of Geography, 62, 2, pp. 50-51.

Beylich, A.A.; Lamoureux, S.F. \& Decaulne, A. (in press). Developing quantitative frameworks for studies on sedimentary fluxes and budgets in changing cold environments. Polish Polar Research.

Beylich, A.A.; Molau, U.; Luthbom, K. \& Gintz, D. (2005). Rates of chemical and mechanical fluvial denudation in an Arctic-oceanic periglacial environment, Latnjavagge drainage basin, northernmost Swedish Lapland. Arctic, Antarctic, and Alpine Research, 37, 1, pp. 75-87.

Beylich, A.A. \& Sandberg, O. (2005). Geomorphic effects of the extreme rainfall event of 2021 July, 2004 in the Latnjavagge catchment, northern Swedish Lapland. Geografiska Annaler, 87A, pp. 409-419.

Beylich, A.A.; Sandberg, O.; Molau, U. \& Wache, S. (2006b). Intensity and spatio-temporal variability of fluvial sediment transfers in an Arctic-oceanic periglacial environment in northernmost Swedish Lapland (Latnjavagge catchment). Geomorphology, 80, pp. 114-130.

Beylich, A.A. \& Warburton, J. (Eds) (2007). Analysis of Source-to-Sink-Fluxes and Sediment Budgets in Changing High-Latitude and High-Altitude Cold Environments. SEDIFLUX Manual. NGU Report, 2007.053. 158pp.

Büdel, J. (1981). Klima-Geomorphologie. 2., veränderte Auflage, Berlin, Stuttgart.

Burki, V.; Hansen, L.; Fredin, O.; Andersen, T.A.; Beylich, A.A.; Jaboyedoff, M.; Larsen, E. \& Tønnesen, J.-F. (2009). Little Ice Age advance and retreat sediment budgets for an outlet glacier in western Norway. Boreas, 10.1111/j.1502-3885.2009.00133.x.ISSN 0300-9483

Caine, N. (1974). The geomorphic processes of the alpine environment. In: Ives, J.D. \& Barry, R.G. (Eds). Arctic and Alpine Environments. Methuen, pp. 721-748.

Caine, N. (2004). Mechanical and chemical denudation in mountain systems. In: Owens, P.N. \& Slaymaker, O. (Eds.). Mountain Geomorphology. Arnold, London.

Caine, N. \& Swanson, F.J. (1989). Geomorphic coupling of hillslope and channel systems in two small mountain basins. Zeitschrift für Geomorphologie, 33, pp. 189-203.

Cockburn, J.M.H. \& Lamoureux, S.F. (2007). Hydroclimate controls over seasonal sediment yield in two adjacent high arctic watersheds. Hydrological Processes, doi: 10.1002/hyp.6798 
Dixon, J.C.; Thorn, C.E. \& Darmody, R.G. (2008). Spatial scale and chemical weathering in Kärkevagge: Influences on landscape evolution. Zeitschrift für Geomorphologie N.F., 52,1 , pp. 27-49.

Dowdeswell, J.A.; Ottesen, D. \& Rise, L. (2006). Flow switching and large-scale deposition by ice streams draining former ice sheets. Geology, 34, pp. 313-316.

Evans, S.G. \& Clague, J.J. (1994). Recent climate change and catastrophic geomorphic processes in mountain environments. Geomorphology, 10, pp. 107-128.

French, H.M. (1996). The Periglacial Environment. $2^{\text {nd }}$ ed., London.

Gurnell, A.M. \& Clark, M.J. (Eds) (1987). Glacio-fluvial sediment transfer: An Alpine Perspective. Chichester, Wiley.

Haeberli, W. \& Beniston, M. (1998). Climate change and its impacts on glaciers and permafrost in the Alps. Ambio, 27, pp. 258-265.

Hansen, L.; Beylich, A.A.; Burki, V.; Eilertsen, R.; Fredin, O.; Larsen, E.; Lyså, A.; Nesje, A.; Stalsberg, K. \& Tønnesen, J.-F. (2009). Stratigraphic architecture and infill history of a deglaciated bedrock valley based on georadar, seismic profiling and drilling. Sedimentology, 56, pp. 1751-1773.

Jäckli, H. (1957). Gegenwartsgeologie des Bündnerischen Rheingebietes. Beitrag zur Geologischen Karte der Schweiz, Geotechn. Serie, 36.

Lamoureux, S.F. (1999). Spatial and inter-annual variations in sedimentation patterns recorded in nonglacial varved sediments from the Canadian high Arctic. Jburnal of Paleolimnology, 21, pp. 73-84.

Lamoureux, S.F.; Beylich, A.A. \& Decaulne, A. (2007): Sediment Fluxes and Budgets in High-Latitude and High-Altitude Cold Environments. Sediment Budgets in Cold Environments (SEDIBUD) Second Workshop; Abisko, Sweden, 15-19 September 2007. EOS, Vol. 88, 52, 25 December 2007: 580.

Orwin, J.F. \& Smart, C.C. (2004). Short-term spatial and temporal patterns of suspended sediment transfer in proglacial channels, Small River Glacier, Canada. Hydrological Processes, 18, pp. 1521-1542.

Otto, J.-C. \& Dikau, R. (2004). Geomorphologic system analysis of a high mountain valley in the Swiss Alps. Zeitschrift für Geomorphologie, 48, pp. 323-341.

Rapp, A. (1960). Recent development of mountain slopes in Kärkevagge and surroundings, Northern Scandinavia. Geografiska Annaler, 42, pp. 71-200.

Rapp, A. (1985). Extreme rainfall and rapid snowmelt as causes of mass movements in high latitude mountains. In: Church, M. \& Slaymaker, O. (Eds). Field and theory: lectures in geocryology. University of British Columbia Press, Vancouver, pp. 36-56.

Reid, L.M. \& Dunne, T. (1996). Rapid evaluation of sediment budgets. Cremlingen, Catena.

Reynolds, J.M. (1997). An introduction to applied and environmental geophysics. Wiley, Chichester.

Rise, L.; Ottesen, D.; Berg, K. \& Lundin, E. (2005). Large-scale development of the midmorwegian margin during the last 3 million years. Marine and Petroleum Geology, 22, pp. 33-44.

Sass, O. (2005). Spatial patterns of rockfall intensity in the northern Alps. Zeitschrift für Geomorphologie N.F., Suppl.-Bd. 138, pp. 51-65.

Schrott, L.; Hufschmidt, G.; Hankammer, M.; Hoffmann, T. \& Dikau, R. (2003). Spatial distribution of sediment storage types and quantification of valley fill deposits in an alpine basin, Reintal, Bavarian Alps, Germany. Geomorphology, 55, pp. 45-63. 
Schrott, L.; Niederheide, A.; Hankammer, M.; Hufschmidt, G. \& Dikau, R. (2002). Sediment storage in a mountain catchment: geomorphic coupling and temporal variability (Reintal, Bavarian Alps, Germany). Zeitschrift für Geomorphologie N.F., Suppl. 127, pp. 175-196.

Slaymaker, O. (2000). Research developments in the hydrological sciences in Canada (19951998): Surface water - quantity, quality and ecology. Hyrological Processes, 14, pp. 1539-1550.

Slaymaker, O., (2008). Sediment budget and sediment flux studies under accelerating global change in cold environments. Zeitschrift für Geomorphologie N.F., 52, 1, pp. 123-148.

Slaymaker, O.; Souch, C.; Menounos, B. \& Filippelli, G. (2003). Advances in Holocene mountain geomorphology inspired by sediment budget methodology. Geomorphology, 55, pp. 305-316.

Strömquist, L. \& Rehn, J. (1981). Rainfall measurements, runoff and sediment transport in Kärkevagge, Swedish Lapland. Transactions, clapanese Geomorphological Union, 2, pp. 211-222.

Tricart, J. (1970). Geomorphology of cold environments. London.

Warburton, J. (1993). Energetics of Alpine proglacial geomorphic processes. Transactions of the Institute of British Geographers, 18, pp. 197 - 206.

Warburton, J. (2006). Mountain Environments. In: Perry, C. \& Taylor, K. (Eds). Environmental Sedimentology. Blackwell, Oxford.

Warburton, J. (2007): Sediment budgets and rates of sediment transfers across cold environments in Europe: a commentary. Geografiska Annaler, 89A, 1, pp. 95-100. 


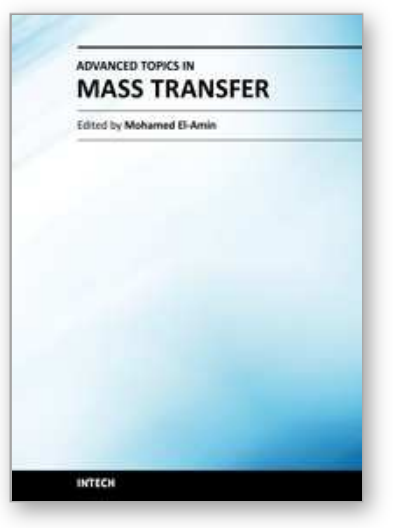

\author{
Advanced Topics in Mass Transfer \\ Edited by Prof. Mohamed El-Amin
}

ISBN 978-953-307-333-0

Hard cover, 626 pages

Publisher InTech

Published online 21, February, 2011

Published in print edition February, 2011

This book introduces a number of selected advanced topics in mass transfer phenomenon and covers its theoretical, numerical, modeling and experimental aspects. The 26 chapters of this book are divided into five parts. The first is devoted to the study of some problems of mass transfer in microchannels, turbulence, waves and plasma, while chapters regarding mass transfer with hydro-, magnetohydro- and electro- dynamics are collected in the second part. The third part deals with mass transfer in food, such as rice, cheese, fruits and vegetables, and the fourth focuses on mass transfer in some large-scale applications such as geomorphologic studies. The last part introduces several issues of combined heat and mass transfer phenomena. The book can be considered as a rich reference for researchers and engineers working in the field of mass transfer and its related topics.

\title{
How to reference
}

In order to correctly reference this scholarly work, feel free to copy and paste the following:

Achim A. Beylich (2011). Mass Transfers and Sedimentary Budgets in Geomorphologic Drainage Basin Studies, Advanced Topics in Mass Transfer, Prof. Mohamed El-Amin (Ed.), ISBN: 978-953-307-333-0, InTech, Available from: http://www.intechopen.com/books/advanced-topics-in-mass-transfer/mass-transfers-andsedimentary-budgets-in-geomorphologic-drainage-basin-studies

\section{INTECH}

open science | open minds

\author{
InTech Europe \\ University Campus STeP Ri \\ Slavka Krautzeka 83/A \\ 51000 Rijeka, Croatia \\ Phone: +385 (51) 770447 \\ Fax: +385 (51) 686166 \\ www.intechopen.com
}

\author{
InTech China \\ Unit 405, Office Block, Hotel Equatorial Shanghai \\ No.65, Yan An Road (West), Shanghai, 200040, China \\ 中国上海市延安西路65号上海国际贵都大饭店办公楼405单元 \\ Phone: +86-21-62489820 \\ Fax: $+86-21-62489821$
}


(C) 2011 The Author(s). Licensee IntechOpen. This chapter is distributed under the terms of the Creative Commons Attribution-NonCommercialShareAlike-3.0 License, which permits use, distribution and reproduction for non-commercial purposes, provided the original is properly cited and derivative works building on this content are distributed under the same license. 